\title{
Examining the Determinants of Job Satisfaction among Tourism
}

\author{
ADELAIDA LILLO-BAÑULS \\ Departamento de Análisis Económico Aplicado and Instituto Universitario de Investigaciones \\ Turísticas (IUIT), Universidad de Alicante, Ap. Correos 99, E-03080 Alicante, Spain \\ E-mail: alillo@ua.es \\ JOSÉ M. CASADO-DÍAZ \\ Departamento de Análisis Económico Aplicado and Instituto Universitario de Investigaciones \\ Turísticas (IUIT), Universidad de Alicante, Ap. Correos 99, E-03080 Alicante, Spain \\ E-mail: jmcasado@ua.es

\section{HIPÓLITO SIMÓN} \\ Departamento de Análisis Económico Aplicado and Instituto Universitario de Economía \\ Internacional (IEI), Universidad de Alicante, Ap. Correos 99, E-03080 Alicante, Spain, and \\ IEB, Facultat d'Economia i Empresa, Universitat de Barcelona, Barcelona, Spain \\ E-mail: hsimon@ua.es
}

\begin{abstract}
Employees' job satisfaction influences their commitment, affects quality and productivity, and is therefore crucial for a labour-intensive industry such as Tourism. In this article the determinants of job satisfaction are examined in comparative terms for tourism workers versus those employed in the rest of the service sector. In contrast with previous research, the analysis is not restricted to hospitality workers, includes all types of occupations, and is based on a nationwide representative sample. The explanatory models of job satisfaction are estimated using ordered logit techniques, considering personal and household characteristics as well as objective and subjective job characteristics. The results indicate that job satisfaction is significantly lower among tourism workers and that in some cases notable differences exist between the factors influencing job satisfaction in the tourism sector compared with the rest of the service sector, which might be relevant for managers and policymakers.
\end{abstract}

Keywords: job satisfaction, tourism industry, tourism workers, Spain

JEL Classification: (J28, L83, Z30).

\section{Introduction}

It is well known that the tourism sector attracts people with different backgrounds, often belonging to some of the less favoured parts of the economically active population. However, the sector's negative features, including higher rates of temporary and part-time work, worse working 
conditions, and lower levels of job tenure and earnings, among other factors, have resulted in a poor image (Baum, 2007 and 2015). This generates recruitment and retention difficulties, coupled with high turnover and vacancy rates in many countries, as recognised by the OECD. The potential impacts of these effects are of paramount importance in countries like Spain, where, according to the OECD, tourism contributes around 11\% of GDP to the national economy (the largest share among OECD countries). Spain's tourism industry is also highly relevant in terms of jobs, employing 2.2 million people, or $12.7 \%$ of total employment (again the largest share among OECD countries). These figures are especially significant in a country where unemployment rates rose above $25 \%$ during the worse years of the Great Recession, when tourism proved to be one of the most resilient economic sectors in terms of both relative added value and job creation and retention.

Job satisfaction is a factor that influences workers' commitment and performance, and thus exerts a significant effect on quality, productivity and profitability. There is evidence, for example, indicating that lower levels of satisfaction are related to a higher incidence of absenteeism and labour turnover (Freeman, 1978; Clark, 2001; Shields and Ward, 2001; Green, 2010), and that job satisfaction is a good predictor for quits (more satisfied workers are less likely to quit; see Freeman, 1978; Akerlof et al, 1988; and Clark et al., 1998). More generally, the meta-analyses by Harter et al. (2002) and Judge et al. (2001), and the reviews by Warr (1999) and Argyle (2001) conclude that there is a generalisable relationship between employee satisfaction, job performance, employees' willingness to help co-workers and their organisation, and business outcomes. This is also the case for the tourism industry. Thus, authors like Gunlu et al. (2010), Back et al. (2011) and López-Cabarcos et al. (2014) point out that job satisfaction among hospitality workers is a significant determinant of commitment, Yang (2010) concludes that job satisfaction contributes to lower employee turnover intention, and Pan (2015:84) states that "no profit can be gained without satisfied employees [since] job satisfaction is generally accepted as one of the primary predictors of productivity". A better understanding of job satisfaction and its determinants and, more specifically, an exploration of which factors differentiate the tourism sector from other comparable parts of the economy is crucial to addressing recruitment and retention difficulties and improving job performance and business outcomes within this sector.

Many works focusing on the economy as a whole have shown that job satisfaction is mainly determined by a worker's individual characteristics (such as sex, age, and education, among others), working conditions (including working hours, working schedule, type of contract, tenure, supervisory duties, and health and safety conditions), and wages. Thus, for example, a generally U-shaped relationship is observed between age and job satisfaction; women are generally more satisfied with their jobs than men; and pay is generally recognised as one of the most relevant predictors of job satisfaction. However, previous literature on this issue for the tourism industry has been constrained by the fact that it has mainly focused on the hotel sector, in many cases concentrating on very specific groups of workers. Moreover, such analyses are frequently based on ad-hoc surveys including few establishments and/or individuals. This has in turn hampered both the generalisation of the findings to the whole hospitality or tourism industry and the comparison of results with other relevant sectors; this is a significant issue, since significant differences in job satisfaction among economic sectors have been documented (Rahman and Sanzi, 1995; Dueñas et al., 2010).

In contrast with many such works, in this study the determinants of job satisfaction are analysed using a large sample representative at the national level (for a country recognised as a very relevant actor in the sector). The sample includes information about all types of workers and allows for a comparative approach where job satisfaction in the entire tourism sector is examined relative to the rest of the service sector - where most workers would plausibly perform their job search if they left the tourism industry.

The article is based on a sample of 13,717 individuals representative of the Spanish labour market for the 2008-2010 period. The descriptive analysis of the database shows that job satisfaction in tourism is lower than in the rest of the service sector. Part of this difference could be associated 
with the fact that working conditions tend to be worse in the tourism sector, as has been widely documented in the literature and is also shown in this study. However, it could also be due to the different impact that such working conditions may have on workers' perceptions at the individual level in the two parts of the economy, pointing to the need for performing more detailed analysis. The empirical part of the article, which uses ordered logit models, focuses on two main questions. On the one hand, it shows that, after controlling for a large set of variables known to explain job satisfaction levels (i.e., when only similar workers in terms of the characteristics considered are compared), such levels are lower among tourism workers than in the rest of the service sector. In other words, the lower satisfaction levels among tourism workers cannot only be explained by a composition effect. On the other hand, the determinants of job satisfaction among tourism employees are explored in detail, adopting a comparative approach vis-à-vis the rest of the service sector. Thus, separate analyses show that, although there are many similarities, it is possible to identify a number of significant differences between the factors influencing job satisfaction in the two worker groups. For instance, seniority is positively related to satisfaction in the tourism industry and is not significant in explaining it in the rest of the service sector; regarding the work schedule, night shifts are negatively related to job satisfaction while the opposite applies to rotating shifts, whereas none of these variables is significant in the rest of the service sector; and the variable identifying women in skilled occupations is significant and takes a negative sign in tourism, but is not significant in the other part of the service sector. Moreover, a number of characteristics identified as significant in explaining job satisfaction in the non-tourism service sector are not relevant for tourism workers. These include marital status, nationality, working in larger firms and holding higher education degrees, as well as working part time and having supervisory roles. We argue that the examination of the diverse factors that contribute to these perceptions can be crucial, since the conclusions arising from such analysis can help managers and policymakers to design, implement and monitor effective measures that could contribute to increasing individual well-being, job performance and, hence, business results.

\section{Background}

Interest among both international organisations and social scientists in the analysis of individual well-being has grown in recent years. This has resulted in a widening of the range of disciplines attracted by such issues beyond the field where most research used to be conducted in previous decades - Psychology. One example of this expanded interest is the OECD Better Life initiative, which is composed, among other elements, of the calculation of the Better Life Index and the periodical publication of its "Measuring Well-being" report (OECD, 2015), where evidence on different aspects of well-being is analysed cross-nationally. Such interest is not new in economic analysis. Thus, for example, seminal works within the specific sphere of job satisfaction include Hamermesh (1977), Freeman (1978) and Borjas (1979). Many other articles published in recent decades have contributed to this literature through the analysis of the determinants and consequences of job satisfaction (see, for example, Zhu, 2013, for a recent review) and its role as part of life satisfaction (see, for example, Veenhoven, 2000, or Erdogan et al., 2012). This body of studies has provided researchers, managers and policymakers with evidence - sometimes clear and others less conclusive - about the main factors influencing job satisfaction. Thus, for example, a variety of papers have examined the comparatively greater job satisfaction observed in women (Oswald, 2002; Clark, 2009; Dueñas et al., 2010); the existence of a negative relationship between job satisfaction and both the level of education (Clark, 1996; Clark and Oswald, 1996) and overeducation (Lillo-Bañuls and Casado-Díaz, 2015); the U-shaped relationship between age and job satisfaction (Clark, Oswald and Warr, 1996); the higher rates of job satisfaction among married workers (Clark, 2009); the positive effect of wages and their increase - together with performing supervisory duties - on workers' job satisfaction (Clark, 1999; and Oswald, 2002); the negative impact on job satisfaction of the length of working hours and lack of job fit (Harter and Arora, 
2008) and fixed-term contracts (Booth et al., 2002; Gamero, 2007); and the positive effect of job stability and promotion prospects (Gamero, 2005). A number of other subjective variables have been analysed and found to be negatively related to satisfaction. These include the levels of pressure or stress at work (Rahman and Sanzi, 1995; Barsky et al., 2004; and Torrent-Sellens et al., 2016), monotony and physical effort (Gamero, 2007; Torrent-Sellens et al., 2016; regarding this variable, Helliwell and Huang, 2008, find that the variety of tasks is positively linked to satisfaction), and whether or not the individual has a hard job (Clark, 2009).

What most of the studies listed in the previous paragraph have in common is the fact that they were carried out using large datasets built to be representative of whole countries, covering all economic sectors, and in some cases even allowing cross-national analyses. Moreover, the range of variables explored and the modelling techniques used have allowed the results to be put into perspective, by considering a wider literature. Previous literature on job satisfaction has, in the case of the tourism industry, focused almost exclusively on the hospitality sub-sector (and on hotels in particular), and in many instances it has concentrated on specific groups of workers and very specific territories/cities. There follow a number of non-comprehensive but illustrative examples. Frye and Mount (2007), who worked with a sample of hotel general managers from a US lodging management company, found that gender, age, educational level and longevity in the hospitality industry have a minimal impact on managers' job satisfaction. This is in contrast with Gunlu et al. (2010), whose results indicate that age and education, together with income level, significantly influence extrinsic job satisfaction among the hotel managers they surveyed in the Aegean region of Turkey. The significance of the reward factor in this sector had already been emphasised by, among others, Pavesic and Brymer (1990), based on a survey of US hospitality graduates, along with working hours and working conditions; and also by Lam, Baum and Pine (2001), and Lam, Zhang and Baum (2001), who analyse the case of hotel managers in Hong Kong and conclude that the work environment, the nature of the job itself, and most notably the rewards associated with it (including job security) are crucial predictors of job satisfaction. Such result is in line with Pan (2015), who analyses a large Taiwanese hotel, finds that compensation is the most significant factor, and states that improving it must be one of the top priorities for fostering higher levels of job satisfaction. However, sometimes the reward system is not found to be a significant variable in explaining job satisfaction in contrast with role clarity, work environment and employees' evaluations of managers' performance (Arnett et al, 2002, who analyse the behaviour of the employees of a large US hotel-casino corporation). In two of the scarce studies regarding the Spanish case, Gallardo et al. (2010) establish the significance of relationships with colleagues and supervisors, workers' perception of the usefulness of their work, and the nature of the work itself, in explaining job satisfaction among a sample of hotel employees in Andalusia; and Varela and García (2006) analyse a sample of hotels in the region of Galicia, concluding that service communicative leadership and service encounter practices influence employee organisational citizenship behaviour and improve job satisfaction among the employees. Training has also been mentioned as a crucial factor influencing job satisfaction (e.g. Conrade and Woods, 1994, who analyse the US lodging industry, and Chun-Fang et al., 2005, who focus on a group of hotels in Kansas and Missouri), particularly among new employees in the hotel industry (Lam, Zhang and Baum, 2001). Based on their analysis of a sample of non-supervisory employees in the hospitality industry in South-east Michigan, Kim and Jogaratnam (2010) find that job characteristics, participative decision-making and stress are good predictors of job satisfaction in the hotel and restaurant industry, while in his study of several Taiwanese hotels, Yang (2010) highlights the roles of conflict, stress, socialisation, and work autonomy in predicting job satisfaction. Regarding seniority, sometimes this is found to be positively linked to job satisfaction (as is the case of the Thailand case study by Sarker et al. 2003). However, in other cases this relationship is negative or length-dependent (Smith, Gregory and Cannon, 1996; Lam, Zhang and Baum, 2001) or there is an absence of statistical significance (Frye and Mount, 2007). Besides concentrating on specific groups of workers, these analyses are quite heterogeneous in terms of both the explanatory variables considered (the ad-hoc nature of the data sources used in many of these articles has allowed the inclusion of more complex constructs compared with the kind of variables usually available from secondary data sources) and the techniques used (e.g. although 
this is an aspect which has not been dealt with in the review, structural equation techniques are over-represented compared with the broader literature on job satisfaction). Moreover, it is noticeable that the overall evidence deriving from these articles shows a lack of agreement as to which variables are significant in explaining job satisfaction and, in some cases, even as to whether certain specific variables exert a positive or a negative effect on job satisfaction. We aim to make a contribution to previous literature by taking advantage of a large sample from a survey specifically designed to facilitate the analysis of working conditions and their relationship with satisfaction and well-being. Such statistical source is representative at the national level and refers to Spain, one of the most significant countries in the sector at a worldwide level. The data source includes information about all types of workers and allows for a comparative approach where job satisfaction not only in hospitality, but in the entire tourism industry, can be examined relative to the rest of the service sector, including most of the variables systematically used in the wider literature on the determinants of job satisfaction.

\section{Data, Variables and Descriptive Analysis}

The Survey on Quality of Life at Work (ECVT in its Spanish acronym) was conducted annually by Spain's Ministry of Employment and Social Security between 1999 and 2010. It is composed of independent cross-sections for each year, which exclusively cover people in work. The survey was designed to offer detailed information on the social and labour conditions of Spanish workers. Therefore, it includes extensive information on workers' individual and household characteristics (sex, age, nationality, level of education, number of children, marital status, etc.); on objective characteristics of their employment (number of hours worked, salary, type of contract, working schedule and occupation, supervisory duties, etc.) and on subjective characteristics based on workers' perceptions (including overall job satisfaction, the dependent variable in our analyses; a self-assessment of over-education; and the perceived levels of monotony and physical effort at the workplace).

The analysis focuses on the most recent ECVT cross-sections, corresponding to the period identified with the Great Recession: 2008-2010. The study has been restricted to employees aged between 16 and 64, which leaves a final sample of 2,362 employees in the tourism sector (tourism activities were considered as such following the methodological recommendations issued by the Instituto de Turismo de España - TURESPAÑA) and 11,355 employees in the rest of the service sector (non-tourism service activities).

The full list of variables considered in this analysis is included in the Appendix (Table A.1). Table 1 summarises the main characteristics of the sample on which the study is based. Overall, this descriptive evidence confirms the predominantly negative features that characterise tourism employment, as found in all the precedent literature. Starting with the variable of interest in the analysis, Table 1 shows that, among tourism workers, overall satisfaction with their current job is lower than for the rest of the service sector (figures A.1 and A.2 plot the differences along the job satisfaction variable distribution for both sub-sectors). Regarding personal characteristics, the percentage of female employees is lower in the tourism sector than in the rest of the service sector $(41.3 \%$ vs. $57.5 \%)$ and no differences are observable in terms of household characteristics. Employees in the tourism sector are slightly younger, are immigrants in a much higher proportion of cases $(18.9 \%$ vs. $7.3 \%)$ and are much less educated than those working in non-tourism service sector activities. Thus, those with primary and higher education account for $20.7 \%$ and $13.8 \%$, respectively, of the employees in the tourism sector, while the respective figures for the rest of the service sector are $11.8 \%$ and $37.7 \%$. Regarding objective labour characteristics, monthly wages are lower in the tourism sector $(€ 1,228$ vs. $€ 1,395)$, while the number of hours worked per week is higher ( 40 vs. 37 ). Seniority is lower in the tourism sector ( 7.6 years in tourism vs. almost 
11 in the rest of the service sector). Firms in the tourism sector are much smaller than in nontourism services (e.g. firms with less than 10 employees account for $33.3 \%$ of the total number of firms in tourism and approximately $20 \%$ in the rest of the service sector), and large differences are observable as regards the type of contract and working schedule. Thus, the number of fixedterm contracts is higher in tourism activities, and so is the frequency of split shifts, shift work, night shifts and jobs that involve working during the weekend (in the latter two cases the proportion of affected workers in tourism more than doubles that for the rest of the service sector). Moreover, workers with supervisory duties are fewer in number in the tourism sector where, unlike the rest of the service sector, skilled occupations are much less frequent $(15.62 \% \mathrm{vs}$. 47.04\%). Most notably, only $7.11 \%$ of them are held by women, while the female presence in such occupations is four times larger in the rest of the service sector. Regarding subjective variables, Table 1 shows that the percentage of tourism employees that perceive themselves as over-educated (those stating that their occupation has requirements that are lower than the level of education they hold) is higher in the tourism sector (22.3\% vs. 20.3\%). Finally, tourism workers report higher levels of monotony and, especially, physical effort compared with the rest of the service sector.

\begin{tabular}{|c|c|c|c|c|c|}
\hline & Services & Tourism & $\begin{array}{l}\text { Rest of service } \\
\text { sector }\end{array}$ & $\begin{array}{r}\text { Difference } \\
\text { (tourism-no } \\
\text { tourism servi } \\
\%^{\mathrm{a}}\end{array}$ & \\
\hline Job satisfaction (0-10 scale) & $\begin{array}{l}7.3776 \\
(1.7283) \\
\end{array}$ & $\begin{array}{l}7.2168 \\
(1.8032)\end{array}$ & $\begin{array}{l}7.4111 \\
(1.7105)\end{array}$ & -2.6 & $*$ \\
\hline Female & $\begin{array}{l}.5471 \\
(.4978)\end{array}$ & $\begin{array}{l}.4128 \\
(.4924)\end{array}$ & $\begin{array}{l}.5751 \\
(.4944)\end{array}$ & -28.2 & $*$ \\
\hline Age & $\begin{array}{l}41.5498 \\
(10.5463)\end{array}$ & $\begin{array}{l}40.1685 \\
(10.5669)\end{array}$ & $\begin{array}{l}41.8371 \\
(10.5197)\end{array}$ & -4.0 & $*$ \\
\hline $\mathrm{Age}^{2}$ & $\begin{array}{l}1837.598 \\
(885.4582)\end{array}$ & $\begin{array}{l}1725.121 \\
(864.172)\end{array}$ & $\begin{array}{l}1860.995 \\
(888.0712)\end{array}$ & -7.3 & $*$ \\
\hline Lives in couple & $\begin{array}{l}.6476 \\
.4777)\end{array}$ & $\begin{array}{l}.6545 \\
(.4756)\end{array}$ & $\begin{array}{l}.6461 \\
(.4782)\end{array}$ & 1.3 & n.s \\
\hline Has children aged 14 and younger & $\begin{array}{l}.3423 \\
(.4745)\end{array}$ & $\begin{array}{l}.3493 \\
(.4768)\end{array}$ & $\begin{array}{l}.3409 \\
(.474)\end{array}$ & 2.5 & n.s \\
\hline Immigrant & $\begin{array}{l}.0932 \\
(.2907)\end{array}$ & $\begin{array}{l}.1892 \\
(.3918)\end{array}$ & $\begin{array}{l}.0732 \\
(.2604)\end{array}$ & 158.5 & $*$ \\
\hline \multicolumn{6}{|l|}{ Education } \\
\hline Primary education & $\begin{array}{l}.1331 \\
(.3397)\end{array}$ & $\begin{array}{l}.207 \\
(.4053)\end{array}$ & $\begin{array}{l}.1177 \\
(.3223)\end{array}$ & 75.9 & $*$ \\
\hline Secondary Education & $\begin{array}{l}.5314 \\
(.499)\end{array}$ & $\begin{array}{l}.655 \\
(.4755)\end{array}$ & $\begin{array}{l}.5057 \\
(.5)\end{array}$ & 29.5 & $*$ \\
\hline Higher education & $\begin{array}{l}.3355 \\
(.4722) \\
\end{array}$ & $\begin{array}{l}.138 \\
(.345) \\
\end{array}$ & $\begin{array}{l}.3766 \\
(.4845) \\
\end{array}$ & -63.4 & $*$ \\
\hline Monthly wage $(€)$ & $\begin{array}{l}1365.977 \\
(699.9602)\end{array}$ & $\begin{array}{l}1228.578 \\
(596.3911)\end{array}$ & $\begin{array}{l}1394.558 \\
(716.3534)\end{array}$ & -11.9 & $*$ \\
\hline Hours worked per week & $\begin{array}{l}37.7228 \\
(9.5291)\end{array}$ & $\begin{array}{l}40.0648 \\
(10.9072)\end{array}$ & $\begin{array}{l}37.2356 \\
(9.142)\end{array}$ & 7.6 & $*$ \\
\hline Seniority (years) & $\begin{array}{l}10.3584 \\
(10.2548)\end{array}$ & $\begin{array}{l}7.6355 \\
(8.7622)\end{array}$ & $\begin{array}{l}10.9248 \\
(10.4504)\end{array}$ & -30.1 & $*$ \\
\hline \multicolumn{6}{|l|}{ Firm size (number of workers) } \\
\hline Less than 10 & $\begin{array}{l}.224 \\
(.417)\end{array}$ & $\begin{array}{l}.3332 \\
(.4715)\end{array}$ & $\begin{array}{l}.2013 \\
(.401)\end{array}$ & 65.5 & $*$ \\
\hline $10-249$ & $\begin{array}{l}.3381 \\
(.4731)\end{array}$ & $\begin{array}{l}.4107 \\
(.4921)\end{array}$ & $\begin{array}{l}.323 \\
(.4677)\end{array}$ & 27.2 & $*$ \\
\hline More than 250 & $\begin{array}{l}.4379 \\
(.4961)\end{array}$ & $\begin{array}{l}.2561 \\
(.4366)\end{array}$ & $\begin{array}{l}.4756 \\
(.4994)\end{array}$ & -46.2 & $*$ \\
\hline \multicolumn{6}{|l|}{ Type of contract } \\
\hline Fixed-term & $\begin{array}{l}.2063 \\
(.4047)\end{array}$ & $\begin{array}{l}.2638 \\
(.4408)\end{array}$ & $\begin{array}{l}.1944 \\
(.3957)\end{array}$ & 35.7 & $*$ \\
\hline Part-time & .1637 & .1732 & .1618 & 7 & n.s \\
\hline
\end{tabular}




\begin{tabular}{|c|c|c|c|c|c|}
\hline & $(.3701)$ & $(.3785)$ & $(.3683)$ & & \\
\hline \multicolumn{6}{|l|}{ Working schedule } \\
\hline \multirow[t]{2}{*}{ Continuous working day } & .6392 & .6202 & .6432 & -3.6 & $* *$ \\
\hline & $(.4802)$ & $(.4854)$ & $(.4791)$ & & \\
\hline \multirow[t]{2}{*}{ Night shift } & .1513 & .2955 & .1213 & 143.6 & * \\
\hline & $(.3583)$ & $(.4564)$ & $(.3265)$ & & \\
\hline \multirow[t]{2}{*}{ Rotating shift } & .2075 & .2934 & .1896 & 54.7 & $*$ \\
\hline & $(.4055)$ & $(.4554)$ & $(.392)$ & & \\
\hline \multirow[t]{2}{*}{ Works weekends } & .1852 & .3561 & .1497 & 137.9 & $*$ \\
\hline & $(.3885)$ & $(.4789)$ & $(.3568)$ & & \\
\hline \multirow[t]{2}{*}{ One-way commuting time ( $\min$ ) } & 21.3561 & 19.8006 & 21.6796 & -8.7 & $*$ \\
\hline & $(18.7468)$ & $(17.3341)$ & $(19.0122)$ & & \\
\hline \multirow[t]{2}{*}{ Supervisory duties } & .1995 & .1837 & .2027 & -9.4 & $* *$ \\
\hline & $(.3996)$ & $(.3874)$ & $(.4021)$ & & \\
\hline \multicolumn{6}{|l|}{ Type of occupation } \\
\hline \multirow[t]{2}{*}{ Skilled } & .4163 & .1562 & .4704 & -66.8 & $*$ \\
\hline & $(.493)$ & $(.3631)$ & $(.4991)$ & & \\
\hline \multirow{2}{*}{ Of which women } & .2299 & .0711 & .2629 & -73.0 & $*$ \\
\hline & $(.4208)$ & $(.2571)$ & $(.4402)$ & & \\
\hline \multirow[t]{2}{*}{ Semi-skilled } & .4542 & .7375 & .3952 & 86.6 & $*$ \\
\hline & $(.4979)$ & $(.4401)$ & $(.4889)$ & & \\
\hline \multirow[t]{2}{*}{ Unskilled } & .1295 & .1063 & .1344 & -20.9 & $*$ \\
\hline & $(.3358)$ & $(.3082)$ & $(.3411)$ & & \\
\hline \multicolumn{6}{|l|}{ Level of (0-10 scale): } \\
\hline \multirow{2}{*}{ Monotony / routine } & 4.9102 & 5.30 & 4.85 & 9.3 & * \\
\hline & $(3.0817)$ & $(3.11)$ & $(3.03)$ & & \\
\hline \multirow[t]{2}{*}{ Physical effort } & 4.2619 & 4.95 & 4.10 & 20.7 & $*$ \\
\hline & (3.1548) & $(3.10)$ & $(3.12)$ & & \\
\hline \multirow[t]{2}{*}{ Over-educated } & .206 & .2227 & .2026 & 9.9 & $* *$ \\
\hline & $(.4045)$ & $(.4161)$ & $(.4019)$ & & \\
\hline $\mathrm{Nu}$ & 13,717 & 2,362 & 11,355 & & \\
\hline
\end{tabular}

Notes: Mean and SD in brackets. ${ }^{a}$ n.s: non significance, significance levels $* 1 \%$, $* * 5 \%$, $* * * 10 \%$, refer to a two-sample $\mathrm{t}$ test of the null hypothesis that the population mean of the variable is the same for both categories within each sample: tourism and non-tourism services. The test does not assume that populations have equal variance.

Source: Authors' own calculations based on the Survey of Quality of Life at Work 2008-2010 (Ministry of Employment and Social Security).

\section{Methodology}

For the analysis carried out in this study, the dependent variable is job satisfaction, as reported by the surveyed individuals and measured on a scale from 0 (zero satisfaction) to 10 (high satisfaction). Due to problems related to the interpersonal comparability of satisfaction levels and the fact that satisfaction as a proxy of individual well-being or utility is a strictly ordinal measure, the most common approach used in this type of studies is based on the consideration that the alternatives of the decision process implicitly express an order of utility and therefore have an ordinal character, leading to the recommendation of ordered logit and probit estimation models (see MacKerron, 2012 and Dickerson et al., 2014). In these models the values taken by the dependent variable are irrelevant, with the exception that the greater values correspond to comparatively higher levels of satisfaction. This involves models that treat data as ordinal, as the discrete expression of a continuous latent variable measured in an arbitrary scale, where two sets of parameters are estimated: a coefficient vector used to predict the latent variable using the set of independent variables, and a set of cut-points, which are the values of the latent variable where there is a change in the observed discrete ranking.

For the model used in the study, an ordered logit, it is assumed that the ordinal variable observed is determined by an unobserved latent variable, which is which is in turn determined as a linear function of the independent variables and a set of thresholds. The probability of observing the $i$ result corresponds to the probability that the estimated linear function plus the error term is in the 
range of the estimated thresholds for the dependent variable, where it is assumed that $u$ follows a logistic distribution, hence:

$$
p_{i j}=\operatorname{Pr}\left(y_{j}=i\right)=\operatorname{Pr}\left(K_{i-1}<x_{j} \beta+u \leq K_{i}\right)=\frac{1}{1+\exp \left(-K_{i}+x_{j} \beta\right)}-\frac{1}{1+\exp \left(-K_{i-1}+x_{j} \beta\right)}
$$

Coefficients $\beta_{1}, \beta_{2}, \ldots, \beta_{K}$ are estimated together with thresholds $K_{l}, K_{2}, \ldots, K_{K-l}$ (where $k$ is the number of possible results; $K_{0}$ is taken as $-\infty$ and $K_{k}$ as $+\infty$ ) and these do not have a direct interpretation because they correspond to the latent variable used in the estimation model. The estimated model is a proportional-odds ordered logit model, where it is assumed that the relative magnitudes of the effects of each explanatory variable are constant across the distribution of the dependent variable and both the coefficients and the thresholds are estimated using maximum likelihood. The standard interpretation of the ordered logit coefficient is that for a one unit increase in the predictor (or for the occurrence of the specific effect measured in the case of dichotomous variables) the response variable level is expected to change by its respective regression coefficient in the ordered log-odds scale while the other variables in the model are held constant.

In the study, two sets of models were estimated following an aggregative strategy. The selection of variables was guided by previous literature on the determinants of job satisfaction relating to both the overall economy and the hospitality industry, as reviewed in the Background section, with the restrictions derived from the characteristics of the statistical data source used in the study. Moreover, in contrast with previous research, an additional multiplicative variable accounting for female workers in skilled occupations was added to examine whether the comparatively worse situation of this group of workers in the tourism industry (see, for example, Skalpe, 2007, and Fleming, 2015) is reflected in job satisfaction. The full list of independent variables considered in the various models can be found in the Appendix (Table A.1). The first two sets of variables described in the previous section (individual and household characteristics, on the one hand, and objective occupation and workplace characteristics, on the other) are included in models 1 and 2, while in models 3 and 4 a set of subjective variables (monotony, physical effort and a selfassessment of over-education) is added to the list of regressors). The empirical strategy follows two steps: it starts by testing whether those working in tourism have lower levels of job satisfaction vis-à-vis comparable employees in the rest of the service sector (i.e., those holding the same characteristics), and then examines the determinants of job satisfaction in tourism by adopting a comparative approach relative to the rest of the services sector, where most workers would perform their job search if they left the industry. Accordingly, while models 1 and 3 are estimated for the whole sample (service sector employees) and include a dichotomous variable that identifies those working in the tourism sub-sector, models 2 and 4 are estimated separately for employees in the tourism industry and in the rest of the services sector, and do not logically include that dummy variable.

\section{Results}

As pointed out in the previous section, two different specifications were estimated for the entire service sector and for both tourism and the rest of the service sector separately. Models 1 and 2, where only objective variables are considered, are reported in Table 2, while Table 3 includes the estimations of models 3 and 4, where three subjective variables (over-education, monotony and physical effort) are added.

Starting with models 1 and 3, where the whole sample of services employees is considered, the dummy that identifies tourism sector is significant and takes a negative sign. Thus, even after controlling for many of the variables that, according to the literature, explain individual satisfaction, tourism employees experience lower levels of job satisfaction compared with the rest of the services sector. Therefore, the lower level of satisfaction observed in descriptive analyses (Table 1) cannot be exclusively attributed to a composition effect (e.g. their jobs have worse 
features in terms of what is desirable for job satisfaction) $)^{1}$ and it is plausible that it is at least partially related to differences in how such characteristics influence the satisfaction levels among tourism and non-tourism employees in the service sector. In models 2 and 4, separate analyses of the determinants of job satisfaction are performed for both sub-sectors and this question is therefore explored. ${ }^{2}$

Regarding personal and household characteristics, models 2 and 4 show that two variables are significant in explaining job satisfaction and have an analogous effect on employees in both the Tourism industry and the rest of the Service sector. These are sex (job satisfaction is higher among female workers compared with their male counterparts) and age (a U-shaped relationship is observed between age and job satisfaction). Both results are in line with previous research and common to all economic sectors. Thus, women are usually found to enjoy their job more than men (Clark, 1996; Oswald, 2002; Dueñas et al., 2010), which has sometimes been hypothesised to be linked with their supposedly lower expectations at work, but also to a composition effect (Gamero, 2004). The U-shaped relationship between age and job satisfaction found by most studies is commonly attributed to the fact that young workers "may get down to earth after becoming conscious of their mistaken overconfident initial predictions [which leads them to] eventually experience growing satisfaction with their job in the long run" (Lévy-Garboua et al, 2007: 260-261). The turning points in the age-job satisfaction relationship occur when tourism workers and those in the rest of the service sector reach the ages of 30 and 35, respectively (figures comparable to those found for the overall economy in previous analyses; e.g. Clark and Oswald, 1996, and Clark et al., 1996). Having children is not significant in either case, while living in a couple does not influence tourism workers' job satisfaction (in line with Gallardo et al., 2010) but is significant and has a positive effect in the rest of the service sector (a relationship that has been frequently found in previous analyses referring to the overall economy).

Regarding education, according to model 2 , holding a university degree is significant and has a negative effect on job satisfaction for all service workers, including tourism workers. This result is quite common in the job satisfaction literature. As summarised by Gamero (2007), it can be explained in two ways. Firstly, from a microeconomic point of view, education is seen as an investment whose economic benefits expand throughout the whole life cycle. The estimated negative relationship between education and job satisfaction would therefore indicate that higher incomes deriving from more schooling would be outweighed by well-being losses in other parts of the labour sphere, or simply that employees with a higher educational background have unmet expectations in terms of financial compensation. Secondly, more educated workers have a higher probability of suffering education mismatch, since over-education is much more frequent among them, and this would in turn result in lower satisfaction levels. Quite interestingly, the effect of education found in our analyses depends on whether over-education is considered (model 2) or not (model 4). Table 3 shows that over-education has a negative and significant effect on job satisfaction in all parts of the economy. In fact, over-education has the largest coefficient among all the dichotomous variables considered. When the variable is introduced as a regressor it results in none of the education level variables being significant among Tourism workers, but that is not the case for the rest of the service sector, where the coefficient of the higher education variable declines compared to model 2 but retains its statistical significance and negative sign. Accordingly, while the negative relationship between education and job satisfaction seems to respond to over-education in the case of tourism workers ${ }^{3}$ (this is in fact the non-tested hypothesis

\footnotetext{
${ }^{1}$ An additional analysis, where the tourism dummy is introduced as the single explanatory variable in the model, results in the coefficient being -0.209 . Its relative similitude to the one reported in model 1 corroborates that only a small part of the difference in job satisfaction can be explained by differences in characteristics between both groups of workers.

${ }^{2}$ The evidence obtained in those analyses has, of course, to be carefully considered, since part of the difference could also be explained by the existence of unobserved worker characteristics.

${ }^{3}$ An intermediate model was built from model 2 where only over-education was added. Its results with regard to how this variable behaves are similar to the ones reported in the article for model 4, which, as stated, additionally includes monotony and physical effort among the regressors.
} 
forwarded by Gallardo et al., 2010), this variable cannot account for the whole effect on employees in the rest of the service sector, for which the first explanation could be more relevant, therefore pointing to the existence of other factors not accounted for in our analyses.

\begin{tabular}{|c|c|c|c|}
\hline & Model 1 & \multicolumn{2}{|c|}{ Model 2} \\
\hline & Services & Tourism & $\begin{array}{c}\text { Non- } \\
\text { Tourism } \\
\text { services } \\
\end{array}$ \\
\hline Tourism & $\begin{array}{l}-0.164 \\
(0.046)^{* * *}\end{array}$ & - & - \\
\hline Female & $\begin{array}{c}0.237 \\
(0.045)^{* * *}\end{array}$ & $\begin{array}{c}0.253 \\
(0.090) * * *\end{array}$ & $\begin{array}{c}0.222 \\
(0.053)^{* * *}\end{array}$ \\
\hline Age & $\begin{array}{l}-0.069 \\
(0.012)^{* * *}\end{array}$ & $\begin{array}{l}-0.063 \\
(0.026)^{* *}\end{array}$ & $\begin{array}{l}-0.072 \\
(0.013)^{* * *}\end{array}$ \\
\hline Age*Age & $\begin{array}{c}0.001 \\
(0.000)^{* * *}\end{array}$ & $\begin{array}{l}0.001 \\
(0.000)^{* *}\end{array}$ & $\begin{array}{l}0.001 \\
(0.000)^{* * *}\end{array}$ \\
\hline Lives in couple & $\begin{array}{l}0.086 \\
(0.038)^{* *}\end{array}$ & $\begin{array}{c}0.069 \\
(0.093)\end{array}$ & $\begin{array}{l}0.095 \\
(0.042)^{* *}\end{array}$ \\
\hline Has children aged 14 and younger & $\begin{array}{c}0.068 \\
(0.038)^{*}\end{array}$ & $\begin{array}{c}0.105 \\
(0.092)\end{array}$ & $\begin{array}{c}0.063 \\
(0.042)\end{array}$ \\
\hline Immigrant & $\begin{array}{c}0.032 \\
(0.060)\end{array}$ & $\begin{array}{l}-0.014 \\
(0.107)\end{array}$ & $\begin{array}{c}0.080 \\
(0.073)\end{array}$ \\
\hline \multicolumn{4}{|l|}{ Education } \\
\hline Secondary & $\begin{array}{l}-0.232 \\
(0.056)^{* * *}\end{array}$ & $\begin{array}{l}-0.147 \\
(0.104)\end{array}$ & $\begin{array}{l}-0.258 \\
(0.066)^{* * *}\end{array}$ \\
\hline Higher & $\begin{array}{l}-0.479 \\
(0.067)^{* * *}\end{array}$ & $\begin{array}{l}-0.328 \\
(0.151)^{* *}\end{array}$ & $\begin{array}{l}-0.518 \\
(0.077)^{* * *}\end{array}$ \\
\hline Ln wage & $\begin{array}{c}0.615 \\
(0.054)^{* * *}\end{array}$ & $\begin{array}{c}0.473 \\
(0.135)^{* * *}\end{array}$ & $\begin{array}{c}0.665 \\
(0.059)^{* * * *}\end{array}$ \\
\hline Ln hours worked per week & $\begin{array}{l}-0.260 \\
(0.071)^{* * *}\end{array}$ & $\begin{array}{l}-0.475 \\
(0.151)^{* * * *}\end{array}$ & $\begin{array}{l}-0.208 \\
(0.079) * * *\end{array}$ \\
\hline Seniority & $\begin{array}{l}-0.010 \\
(0.002)^{* * *}\end{array}$ & $\begin{array}{c}0.005 \\
(0.006)\end{array}$ & $\begin{array}{l}-0.014 \\
(0.002)^{* * *}\end{array}$ \\
\hline \multicolumn{4}{|l|}{ Firm size } \\
\hline $10-249$ & $\begin{array}{l}-0.044 \\
(0.045)\end{array}$ & $\begin{array}{c}0.026 \\
(0.091)\end{array}$ & $\begin{array}{l}-0.080 \\
(0.053)\end{array}$ \\
\hline 250 or more & $\begin{array}{l}-0.062 \\
(0.047)\end{array}$ & $\begin{array}{c}0.098 \\
(0.108)\end{array}$ & $\begin{array}{l}-0.108 \\
(0.053)^{* *}\end{array}$ \\
\hline \multicolumn{4}{|l|}{ Type of contract } \\
\hline Fixed-term & $\begin{array}{l}-0.215 \\
(0.044)^{* * *}\end{array}$ & $\begin{array}{l}-0.218 \\
(0.101)^{* *}\end{array}$ & $\begin{array}{l}-0.211 \\
(0.049)^{* * *}\end{array}$ \\
\hline Part-time & $\begin{array}{l}-0.128 \\
(0.057)^{* *}\end{array}$ & $\begin{array}{l}-0.140 \\
(0.134)\end{array}$ & $\begin{array}{l}-0.126 \\
(0.063)^{* *}\end{array}$ \\
\hline \multicolumn{4}{|l|}{ Working schedule } \\
\hline Continuous working day & $\begin{array}{l}-0.085 \\
(0.034)^{* *}\end{array}$ & $\begin{array}{l}-0.131 \\
(0.078)^{*}\end{array}$ & $\begin{array}{l}-0.065 \\
(0.038)^{*}\end{array}$ \\
\hline Night shift & $\begin{array}{l}-0.152 \\
(0.050)^{* * *}\end{array}$ & $\begin{array}{l}-0.287 \\
(0.087) * * *\end{array}$ & $\begin{array}{l}-0.064 \\
(0.061)\end{array}$ \\
\hline Rotating shift & $\begin{array}{l}-0.013 \\
(0.044)\end{array}$ & $\begin{array}{c}0.119 \\
(0.085)\end{array}$ & $\begin{array}{l}-0.087 \\
(0.051)^{*}\end{array}$ \\
\hline Works weekends & $\begin{array}{l}-0.134 \\
(0.046)^{* * *}\end{array}$ & $\begin{array}{l}-0.164 \\
(0.086)^{*}\end{array}$ & $\begin{array}{l}-0.106 \\
(0.055)^{*}\end{array}$ \\
\hline Commuting time & $\begin{array}{l}-0.007 \\
(0.001)^{* * *}\end{array}$ & $\begin{array}{l}-0.011 \\
(0.003)^{* * *}\end{array}$ & $\begin{array}{l}-0.007 \\
(0.001)^{* * *}\end{array}$ \\
\hline Supervisory duties & $\begin{array}{c}0.158 \\
(0.039)^{* * *}\end{array}$ & $\begin{array}{c}0.164 \\
(0.096)^{*}\end{array}$ & $\begin{array}{l}0.141 \\
(0.043)^{* * * *}\end{array}$ \\
\hline \multicolumn{4}{|l|}{ Type of occupation } \\
\hline Skilled occupation & $\begin{array}{l}0.110 \\
(0.052)^{* *}\end{array}$ & $\begin{array}{l}0.305 \\
(0.137)^{* *}\end{array}$ & $\begin{array}{c}0.075 \\
(0.057)\end{array}$ \\
\hline Skilled occupation*women & $\begin{array}{l}-0.077 \\
(0.061)\end{array}$ & $\begin{array}{l}-0.438 \\
(0.197)^{* *}\end{array}$ & $\begin{array}{l}-0.025 \\
(0.068)\end{array}$ \\
\hline
\end{tabular}




\begin{tabular}{|c|c|c|c|}
\hline Unskilled & $\begin{array}{l}-0.172 \\
(0.058)^{* * *}\end{array}$ & $\begin{array}{l}-0.183 \\
(0.137) \\
\end{array}$ & $\begin{array}{l}-0.197 \\
(0.065) * * *\end{array}$ \\
\hline Constant & $\begin{array}{c}-3.508 \\
(0.478)^{* * *}\end{array}$ & $\begin{array}{l}-5.031 \\
(1.105)^{* * *}\end{array}$ & $\begin{array}{l}-3.065 \\
(0.534)^{* * *}\end{array}$ \\
\hline$N$ & 13,717 & 2,362 & 11,355 \\
\hline Pseudo $R^{2}$ & 0.0122 & 0.0159 & 0.0121 \\
\hline
\end{tabular}

Note: The standard errors of the variables are robust. Year and region-of-residence dummy variables were also included in the estimations.

Source: Authors' own calculations based on the Survey of Quality of Life at Work 2008-2010 (Ministry of Employment and Social Security).

\begin{tabular}{|c|c|c|c|}
\hline & \multirow{2}{*}{$\begin{array}{l}\text { Model } 3 \\
\text { Services }\end{array}$} & \multicolumn{2}{|c|}{ Model 4} \\
\hline & & Tourism & $\begin{array}{c}\text { Non- } \\
\text { Tourism } \\
\text { services }\end{array}$ \\
\hline Tourism & $\begin{array}{l}-0.117 \\
(0.046)^{* *}\end{array}$ & - & - \\
\hline Female & $\begin{array}{c}0.213 \\
(0.046) * * *\end{array}$ & $\begin{array}{c}0.223 \\
(0.090) * *\end{array}$ & $\begin{array}{l}0.203 \\
(0.053)^{* * *}\end{array}$ \\
\hline Age & $\begin{array}{l}-0.067 \\
(0.012) * * *\end{array}$ & $\begin{array}{l}-0.069 \\
(0.026)^{* * *}\end{array}$ & $\begin{array}{l}-0.070 \\
(0.013) * * *\end{array}$ \\
\hline Age*Age & $\begin{array}{c}0.001 \\
(0.000) * * *\end{array}$ & $\begin{array}{c}0.001 \\
(0.000)^{* *}\end{array}$ & $\begin{array}{l}0.001 \\
(0.000)^{* * *}\end{array}$ \\
\hline Lives in couple & $\begin{array}{l}0.087 \\
(0.038)^{* *}\end{array}$ & $\begin{array}{c}0.063 \\
(0.094)\end{array}$ & $\begin{array}{l}0.096 \\
(0.042)^{* *}\end{array}$ \\
\hline Has children aged 14 and younger & $\begin{array}{c}0.051 \\
(0.038)\end{array}$ & $\begin{array}{c}0.094 \\
(0.093)\end{array}$ & $\begin{array}{c}0.047 \\
(0.042)\end{array}$ \\
\hline Immigrant & $\begin{array}{l}0.123 \\
(0.061)^{* *}\end{array}$ & $\begin{array}{c}0.011 \\
(0.107)\end{array}$ & $\begin{array}{l}0.201 \\
(0.074)^{* * *}\end{array}$ \\
\hline Education & & & \\
\hline Secondary education & $\begin{array}{l}-0.079 \\
(0.058)\end{array}$ & $\begin{array}{c}0.031 \\
(0.107)\end{array}$ & $\begin{array}{l}-0.110 \\
(0.068)\end{array}$ \\
\hline Higher education & $\begin{array}{l}-0.169 \\
(0.070)^{* *}\end{array}$ & $\begin{array}{c}0.186 \\
(0.160)\end{array}$ & $\begin{array}{l}-0.233 \\
(0.080)^{* * *}\end{array}$ \\
\hline Ln wage & $\begin{array}{c}0.336 \\
(0.054) * * *\end{array}$ & $\begin{array}{c}0.239 \\
(0.135)^{*}\end{array}$ & $\begin{array}{l}0.382 \\
(0.060)^{* * *}\end{array}$ \\
\hline Ln hours worked per week & $\begin{array}{l}-0.188 \\
(0.072) * * *\end{array}$ & $\begin{array}{l}-0.323 \\
(0.149) * *\end{array}$ & $\begin{array}{l}-0.157 \\
(0.082)^{*}\end{array}$ \\
\hline Seniority & $\begin{array}{l}-0.007 \\
(0.002)^{* * *}\end{array}$ & $\begin{array}{c}0.009 \\
(0.006)^{*}\end{array}$ & $\begin{array}{l}-0.010 \\
(0.002)^{* * *}\end{array}$ \\
\hline Firm size & & & \\
\hline $10-249$ & $\begin{array}{l}-0.052 \\
(0.046)\end{array}$ & $\begin{array}{l}-0.003 \\
(0.090)\end{array}$ & $\begin{array}{l}-0.083 \\
(0.053)\end{array}$ \\
\hline 250 or more & $\begin{array}{l}-0.056 \\
(0.047)\end{array}$ & $\begin{array}{c}0.064 \\
(0.108)\end{array}$ & $\begin{array}{l}-0.095 \\
(0.053)^{*}\end{array}$ \\
\hline Type of contract & & & \\
\hline Fixed-term & $\begin{array}{l}-0.235 \\
(0.044) * * *\end{array}$ & $\begin{array}{l}-0.214 \\
(0.099)^{* *}\end{array}$ & $\begin{array}{l}-0.237 \\
(0.049) * * *\end{array}$ \\
\hline Part-time & $\begin{array}{l}-0.138 \\
(0.058)^{* *}\end{array}$ & $\begin{array}{l}-0.032 \\
(0.130)\end{array}$ & $\begin{array}{l}-0.164 \\
(0.064)^{* *}\end{array}$ \\
\hline Working schedule & & & \\
\hline Continuous working day & $\begin{array}{l}-0.040 \\
(0.034)\end{array}$ & $\begin{array}{l}-0.128 \\
(0.079)\end{array}$ & $\begin{array}{l}-0.011 \\
(0.038)\end{array}$ \\
\hline Night shift & $\begin{array}{l}-0.153 \\
(0.050)^{* * *}\end{array}$ & $\begin{array}{l}-0.291 \\
(0.088) * * *\end{array}$ & $\begin{array}{l}-0.071 \\
(0.062)\end{array}$ \\
\hline Rotating shift & $\begin{array}{c}0.036 \\
(0.044)\end{array}$ & $\begin{array}{l}0.187 \\
(0.087)^{* *}\end{array}$ & $\begin{array}{l}-0.041 \\
(0.052)\end{array}$ \\
\hline Works weekends & $\begin{array}{l}-0.070 \\
(0.046)\end{array}$ & $\begin{array}{l}-0.073 \\
(0.088)\end{array}$ & $\begin{array}{l}-0.046 \\
(0.055)\end{array}$ \\
\hline Commuting time & $\begin{array}{l}-0.007 \\
(0.001)^{* * *}\end{array}$ & $\begin{array}{l}-0.008 \\
(0.003) * * *\end{array}$ & $\begin{array}{l}-0.007 \\
(0.001)^{* * *}\end{array}$ \\
\hline
\end{tabular}




\begin{tabular}{|c|c|c|c|}
\hline Supervisory duties & $\begin{array}{l}0.129 \\
(0.039)^{* * *}\end{array}$ & $\begin{array}{c}0.143 \\
(0.098)\end{array}$ & $\begin{array}{l}0.110 \\
(0.043)^{* *}\end{array}$ \\
\hline \multicolumn{4}{|l|}{ Type of occupation } \\
\hline Skilled occupation & $\begin{array}{l}-0.014 \\
(0.053)\end{array}$ & $\begin{array}{c}0.141 \\
(0.139)\end{array}$ & $\begin{array}{l}-0.032 \\
(0.058)\end{array}$ \\
\hline Skilled occupation*women & $\begin{array}{l}-0.115 \\
(0.062) *\end{array}$ & $\begin{array}{l}-0.529 \\
(0.196) * * *\end{array}$ & $\begin{array}{l}-0.067 \\
(0.068)\end{array}$ \\
\hline Unskilled & $\begin{array}{c}0.025 \\
(0.059)\end{array}$ & $\begin{array}{l}-0.025 \\
(0.141)\end{array}$ & $\begin{array}{c}0.007 \\
(0.066)\end{array}$ \\
\hline \multicolumn{4}{|l|}{ Subjective variables } \\
\hline Monotony-routine & $\begin{array}{l}-0.130 \\
(0.006) * * *\end{array}$ & $\begin{array}{l}-0.112 \\
(0.013) * * *\end{array}$ & $\begin{array}{l}-0.134 \\
(0.007) * * *\end{array}$ \\
\hline Physical effort & $\begin{array}{l}-0.033 \\
(0.006) * * *\end{array}$ & $\begin{array}{l}-0.041 \\
(0.013) * * *\end{array}$ & $\begin{array}{l}-0.030 \\
(0.006)^{* * *}\end{array}$ \\
\hline Over-educated & $\begin{array}{l}-0.898 \\
(0.041) * * *\end{array}$ & $\begin{array}{l}-1.049 \\
(0.099) * * *\end{array}$ & $\begin{array}{l}-0.878 \\
(0.045)^{* * *}\end{array}$ \\
\hline Constant & $\begin{array}{l}-6.128 \\
(0.487)^{* * *}\end{array}$ & $\begin{array}{l}-7.200 \\
(1.100)^{* * *}\end{array}$ & $\begin{array}{l}-5.793 \\
(0.548) * * *\end{array}$ \\
\hline$N$ & 13,717 & 2,362 & 11,355 \\
\hline Pseudo $R^{2}$ & 0.0372 & 0.0419 & 0.0372 \\
\hline
\end{tabular}

The second set of variables considered in the models refers to objective occupation and workplace characteristics. Also in this case, certain variables have a similar effect on job satisfaction in tourism and in the rest of the service sector. Thus, while pay has a positive effect, the opposite applies to the number of hours worked per week ${ }^{4}$ and commuting time, as would be expected. Having a temporary job has a negative effect on job satisfaction, a result that is at odds with part of the international literature (Booth et al., 2002; Bardasi and Francesconi, 2003, or Clark, 2005), which does not find a significant link between temporary jobs and satisfaction, but agrees with the findings of Gamero (2007), who analyses the overall Spanish economy, and Gallardo et al. (2010), whose case study refers to the Andalusian hospitality sector. One possible explanation for this is the fact that fixed-term contracts, which in most cases are not voluntarily chosen, can be particularly detrimental in terms of job satisfaction in countries where unemployment rates are particularly high and where those contracts typically involve very short periods of time, as is the case in Spain.

Tables 2 and 3 show that in some cases the variables are significant in explaining job satisfaction for one of the sub-sectors, but not for the other. Thus, part-time work is not significant among tourism employees but exerts a negative effect on job satisfaction in the rest of the service sector, something that cannot be attributed to a different incidence of non-voluntariness, since in both cases the proportion that state being in such a situation is around 65\%. Also, as regards firm size, it is observed that working in larger firms reduces satisfaction among non-tourism service employees but is not a significant variable in explaining job satisfaction in the tourism industry. Having supervisory roles is associated with higher levels of job satisfaction in both parts of the service sector (model 2). However, when monotony, physical effort and over-education are also considered (model 4) this variable is only significant for non-tourism service sector employees.

Regarding working schedule, having a continuous working day and working during the weekends reduce job satisfaction for both groups of workers (model 2), but it is noticeable that neither of these variables is significant when monotony/routine and physical effort are included in the estimations (in model 4 both variables, monotony and physical effort, are statistically

\footnotetext{
${ }^{4}$ One of the reviewers has noted that the difference between both sub-sectors in the absolute value of the associated coefficient magnitude is particularly high in the case of work hours, whose effect on satisfaction is higher in the case of tourism employees, which might have to do with the fact that the average number of hours worked weekly by them is higher.
} 
significant and take a negative sign for both parts of the service sector, although the impact of monotony on job satisfaction is much higher compared with that of physical effort). This result suggests that such factors are behind this effect and could also explain why working in rotating shifts loses its significance for non-tourism employees when both objective and subjective variables are considered (a surprising result in models 3 and 4 is the fact that shift work is significant and positively linked to job satisfaction for tourism workers, which is relevant given the fact that this type of schedule is much more common among them, as shown in Table 1). However when monotony and physical are considered the effect of working night shifts remains the same, and is associated with lower levels of job satisfaction in the tourism sector and not significant in the other part of the service sector. Again, the descriptive evidence displayed in Table 1 indicates that this type of shift is much more frequent among tourism workers (29.5\% vs. $12.1 \%$ ) and is therefore a factor whose impact on average satisfaction is potentially high, but has an effect opposite to that of rotating shifts.

Seniority is one of the variables whose effect on satisfaction has been found to be mixed according to previous literature on tourism workers' job satisfaction. As stated in the background section, it is sometimes found to be positively linked to job satisfaction (Sarker et al. 2003) but in other cases a negative or length-dependent relationship is observed (Smith et al., 1996; Lam, Zhang and Baum, 2001). According to our results, length of tenure is statistically significant in explaining the job satisfaction of tourism employees, with a positive effect, but only when the estimation controls for monotony/routine, among other subjective variables (model 4), which could be associated with a premium of satisfaction in a sector where seniority is much lower compared with other parts of the economy. In contrast, model 2 shows that this variable is negatively linked to satisfaction in the non-tourism service sector, something that the literature has associated with a growing concern about the monotonous and repetitive nature of many jobs, and with the enthusiasm of newcomers, which decreases with time (Lam, Zhang and Baum, 2001). However, such explanation is not fully satisfactory in this case, since in model 4 we control for monotony and routine, and the negative link still persists.

Finally, regarding the type of occupation, when over-education is not included in the estimations (model 2), having skilled occupations increases the satisfaction of tourism employees, while unskilled occupations exert the opposite effect in the rest of the service sector. Both effects disappear, however, when over-education is considered as an additional regressor (model 4), which indicates that the effect captured by these variables in model 2 could be reflecting that having a more skilled occupation reduces the likelihood of being over-educated, while less skilled occupations increase it. Interestingly, the only variable belonging to this group that remains significant in the extended model is the one that identifies women in skilled occupations, who show lower levels of satisfaction. The associated coefficient indicates that this is in fact the second most relevant individual characteristic in terms of its relationship with job satisfaction, after overeducation. The literature on wage discrimination shows that, as in other industries, women in the tourism sector have lower wages even when they hold the same position as their male counterparts. When the analysis focuses on average wages this phenomenon appears to be less relevant in the tourism sector compared with other parts of the economy (Santos and Varejão, 2007; Muñoz-Bullón, 2009), something that has been partially explained by labour market institutions and, in particular, by minimum wage legislation, which provides less room for pay discrimination among low-wage workers in low-wage industries like tourism. However, gender wage differences are especially acute in the higher positions within organisations, where the gender wage gap seems to be larger in the tourism industry compared with other sectors (Skalpe, 2007; Simón et al, 2015; Fleming, 2015; Casado-Díaz and Simón, 2016). We hypothesise that this higher penalty for women in more skilled positions has a relevant implication in terms of their job satisfaction compared with their male counterparts.

\section{Conclusions}


Job satisfaction is a crucial element of both individual well-being and business outcomes, given the well-established links between job satisfaction, job performance and business outcomes. Examining the factors that influence job satisfaction is therefore a relevant exercise, especially because such factors have been shown to vary between different economic sectors. Previous research on job satisfaction within the tourism industry has mainly focused on the hospitality sector, with an over-representation of research on hotel employees, and in many cases a focus on specific occupations. The ad-hoc nature of the primary data on which most of these works are based has allowed them to provide rich insights from specific case studies. However, due to their very nature, the results of these studies are difficult to generalise, and lack a comparative dimension vis-à-vis other sectors of the economy. Moreover, in some cases the evidence obtained is mixed and rather inconclusive, as was noted in the article's background section. The main objective of this article is to identify the significance of both personal and household factors, on the one hand, and objective and subjective characteristics of the job, on the other, in explaining job satisfaction among tourism employees. In contrast with previous analyses, the article refers to the entire tourism industry; is based on a large sample representative of a whole country, Spain, one of the main actors within the world tourism sector; includes information on all types of workers; and adopts a comparative perspective with regard to the other (non-tourism) part of the service sector, where most workers would perform their job search if they left the tourism industry.

The descriptive analysis with which the study begins shows that jobs in the tourism sector are characterised by what conventional wisdom would consider negative features. For example, compared with the rest of the service sector, average tourism employees receive lower pay, work longer hours per week and have lower seniority, and have a much higher proportion of fixed-term contracts, night shifts, rotating shifts, and weekend work. It is not surprising, then, that average job satisfaction is also lower among them. A composition effect could be in play: the difference in satisfaction between tourism employees and those working in the rest of the service sector could be the result of the differences in the distribution of those characteristics between the two worker groups. The first issue on which the empirical part of the article focuses is testing that explanation. It is concluded that even when the differences in characteristics between the average workers are controlled for, the dummy that identifies tourism employees is significant and negatively linked to job satisfaction. This would suggest the possibility that some of those characteristics exert a different effect on satisfaction depending on whether the employee works in tourism or in the other part of the service sector. To fulfil its main objective, the article then goes on to analyse the determinants of job satisfaction for tourism workers, based on the estimation of ordered logit models where job satisfaction is the dependent variable, and adopting a comparative approach vis-à-vis those employed in the rest of the service sector, through the estimation of separate models.

To recapitulate, it is found that, ceteris paribus, within the tourism sector job satisfaction is higher for women; there is a U-shaped relationship between age and job satisfaction, with the turning point reached at the age of 30; job satisfaction increases with pay and decreases with work hours and commuting time, and is lower among workers on fixed-term contracts and those suffering from over-education and higher levels of monotony and physical exertion at work. On the other hand, job characteristics such as having a continuous working day or working during the weekend are not significantly related to job satisfaction. All these factors act in the same way when the rest of the service sector is considered. Interestingly, there are other factors where large differences are observed between both parts of the service sector. Thus, seniority is positively related to satisfaction in the tourism industry and is not significant in explaining it in the rest of the service sector; regarding the work schedule, night shifts are negatively related to job satisfaction while the opposite applies to rotating shifts, whereas none of these variables is significant in the rest of the service sector; and the variable identifying women in skilled occupations is significant and takes a negative sign in tourism, but is not significant in the other part of the service sector. Moreover, a number of characteristics identified as significant in explaining job satisfaction in the non-tourism service sector are not relevant for tourism workers. These include marital status, 
nationality, working in larger firms and holding higher education degrees, as well as working part time and having supervisory roles.

Summing up, our results indicate that policies aimed at addressing job satisfaction in the tourism industry should take into consideration the particular characteristics of the sector, i.e., which specific factors have a more marked effect. For example, it is apparent that certain objective job characteristics usually perceived as negative are valued in a different way by tourism workers, for whom part-time work, for instance, is not significant in explaining job satisfaction and shift work has a positive effect. In addition, the article's findings highlight the need for greater progress in designing polices aimed at improving the recognition of female workers in skilled occupations, or at establishing better incentive schemes to compensate workers in night shifts so that their perception of such shifts improves. Moreover, certain factors whose influence is similar across the whole service sector should also be addressed. These most notably include over-education, but also wage, working hours, the incidence of fixed-term contracts and the level of monotony whose consideration in the estimations has been shown to determine whether certain schedule arrangements such as having a continuous working day or working during the weekend are significant in explaining job satisfaction. As pointed out by the OECD, policymakers and the tourism industry must work together to promote workforce development, a crucial step towards the creation of a more competitive and sustainable sector. Like many others, Tourism is a sector facing new challenges that require more qualified and adaptable employees, i.e., high-quality human resources to create and supply competitive products that meet the needs of an evolving demand. The attraction and retention of such employees is closely related to the creation of better jobs or, in other words, jobs that generate better perceptions among the people that hold them. 


\title{
Table A.1. Explanatory variables included in the models
}

\author{
Individual and household This set of variables includes sex (a dichotomous variable that takes value 1 for female \\ characteristics \\ employees); age (in years) and its square in order to account for likely non-linear \\ (models 1, 2, 3 and 4) \\ effects; nationality (a dichotomous variable that takes value 1 for non-Spanish salaried \\ workers; 0 for Spanish workers); educational attainment (a categorical variable that \\ distinguishes between primary education -the reference category-, secondary education \\ and higher education); marital status (value 1 when the worker lives with their partner; \\ 0 otherwise) and children (value 1 when the individual has children aged 14 and \\ younger; 0 when no children or children over 14 years old).
}

\footnotetext{
Objective occupation and This set of variables includes wage (net monthly wage in logs); hours worked per week workplace characteristics (in logs); seniority (in years); firm size (a variable categorized in less than 10 workers (models 3 and 4) -the reference category-, 10-249 and 250 or more workers); type of contract (two dichotomous variables accounting for fixed-term contracts - the reference category here is indefinite contract - and part-time work - the reference category is full time); working schedule (a group of dichotomous variables that take value 1 for employees that work continuous shift, night shift, rotating shift and during the weekends, respectively, and 0 otherwise); commuting time (one-way, in minutes); supervisory duties (takes value 1 when the employee has this task); type of occupation - in three categories: unskilled, medium skilled - reference category- and skilled; and a multiplicative identifying female workers in skilled occupations).

\begin{tabular}{ll}
\hline Subjective variables & This set of variables includes workers' assessment of the level of monotony/routine and \\
& physical effort associated with their work (on a scale from 0 -minimum degree- to 10 - \\
(model 4) & maximum degree). A dichotomous variable accounting for over-education is included \\
& in models 3 and 4 (such variable takes value 1 when the individual states that their \\
& qualification exceeds that required for current job and 0 otherwise).
\end{tabular}
}




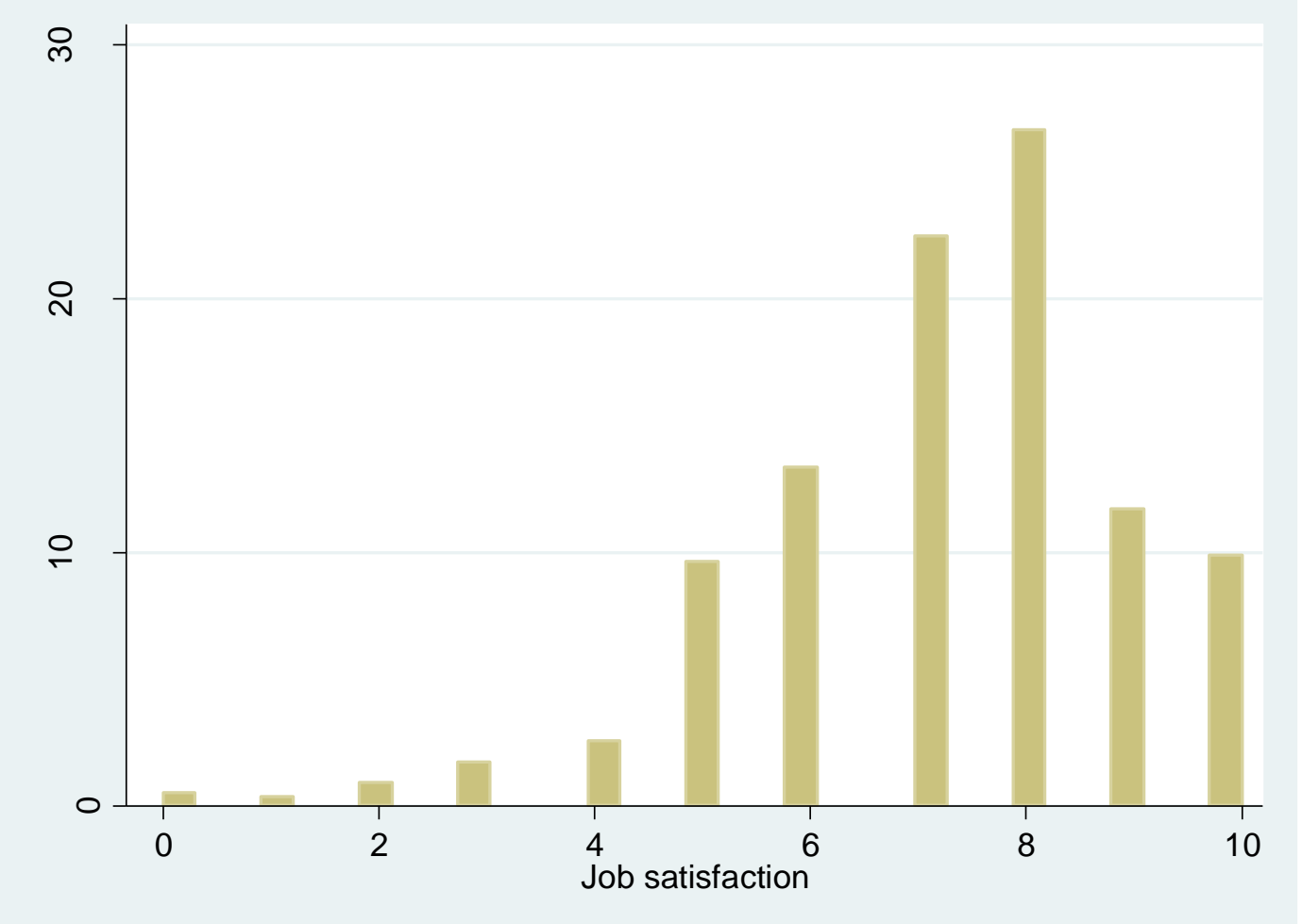

Figure A.1. Tourism service employees. Job satisfaction by level (\%). 


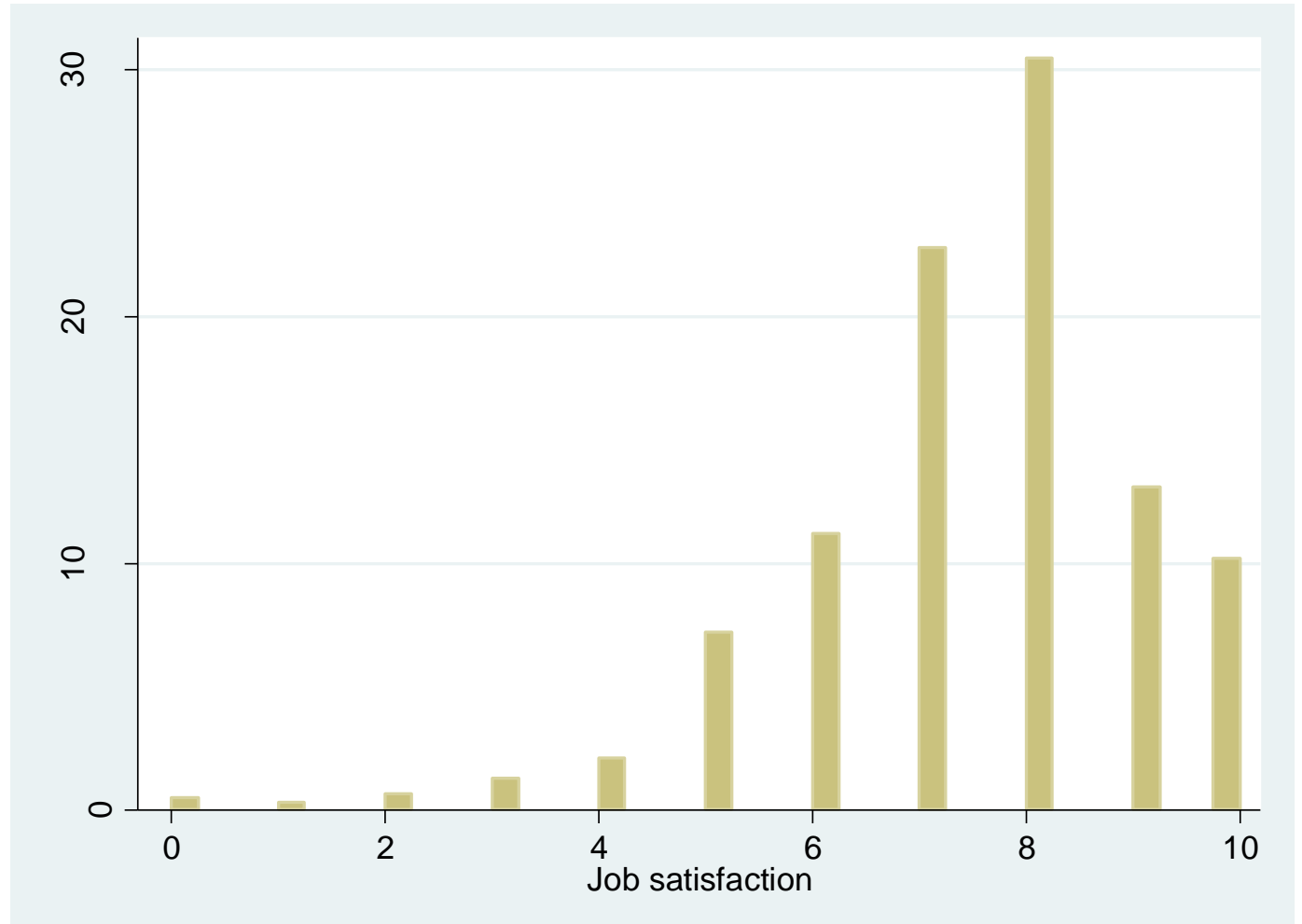

Figure A.2. Non-tourism service employees. Job satisfaction by level (\%).

\section{References}

Akerlof GA, Rose AK and Yellen JL (1988) Job Switching and Job Satisfaction in the US Labor Market. Brooking Papers on Economic Activity 2: 495-594.

Argyle M (2001) The Psychology of Happiness. London: Routledge.

Arnett DB, Laverie DA and McLane C (2002) Using job satisfaction and pride as internal marketing tools. Cornell Hotel and Restaurant Administration Quarterly 43(2): 87-96.

Back KJ, Lee CK and Abbott J (2011) Internal relationship marketing: Korean casino employees' job satisfaction and organizational commitment. Cornell Hospitality Quarterly 52(2): 111-124.

Baum T (2007) Human resources in tourism: Still waiting for change. Tourism Management, 28(6): 1383-1399.

Baum T (2015) Human resources in tourism: Still waiting for change? - A 2015 reprise. Tourism Management, 50: 204-212.

Bardasi E. and Francesconi M (2003) The impact of atypical employment on individual wellbeing: evidence from a panel of British Workers. ISER working paper 2003-02.

Barsky A, Thoresen CJ, Warren CR and Kaplan SA (2004) Modeling negative affectivity and job stress: A contingency-based approach. Journal of Organizational Behavior 25: 915-936.

Booth AL, Francesconi M and Frank J (2002) Temporary jobs: stepping stones or dead ends? Economic Journal 112(480):189-213.

Borjas GJ (1979) Job satisfaction, wages and unions. Journal of Human Resources 14: 21-40.

Casado-Díaz JM and Simón H (2016) Wage differences in the hospitality sector. Tourism Management 52: 96-109. 
Chun-Fang C, Ki-Joon B and Deborah DC (2005) The impact of employee training on job satisfaction and intention to stay in the hotel. Journal of Human Resources in Hospitality \& Tourism 4(2): 99-118.

Clark AE (1996) Job satisfaction in Britain. British Journal of Industrial Relations 34: 189-217.

Clark AE (1999) Are wages habit-forming? Evidence from micro data. Journal of Economic Behaviour and Organization 39: 179-200.

Clark AE (2001) What really matters in a job? Hedonic measurement using quit data. Labour economics 8(2): 223-242.

Clark AE (2005) Your money or your life: Changing job quality in OECD countries. British Journal of Industrial Relations 43: 377-400.

Clark AE (2009) Work, Jobs and Well-Being across the Millennium. IZA Discussion Paper Series No. 3940.

Clark AE, Georgellis Y and Sanfey P (1998) Job Satisfaction, Wage Change and Quits. Research in Labor Economics 17: 95-121.

Clark AE and Oswald AJ (1996) Satisfaction and comparison income. Journal of Public Economics 65: 359-381.

Clark AE, Oswald AJ and Warr PB (1996) Is job satisfaction U-shaped in age? Journal of Occupational and Organizational Psychology 69: 57-81.

Conrade G and Woods RN (1994) Training in the U.S. lodging industry: Perception and reality. Cornell Hotel \& Restaurant Administration Quarterly 35(5): 16-21.

Dickerson A, Hole AR and Munford LA (2014) The relationship between well-being and commuting revisited: Does the choice of methodology matter? Regional Science and Urban Economics 49: 321-329.

Dueñas D, Iglesias C and Llorente R (2010) Job quality, job satisfaction and services in Spain. Journal of Innovation Economics \& Management 2010/1(5): 145-166.

Erdogan B, Bauer TN, Truxillo DM and Mansfield, LR (2012) Whistle while you work a review of the life satisfaction literature. Journal of Management 38(4): 1038-1083.

Fleming SS (2015) Déjà Vu? An Updated Analysis of the Gender Wage Gap in the U.S. Hospitality Sector. Cornell Hospitality Quarterly 56(2): 180-190.

Freeman, RB (1978) Job satisfaction as an economic variable. American Economic Review 68: $135-141$.

Frye WD and Mount DJ (2007) An Examination of Job Satisfaction of General Managers Based on Hotel Size and Service Type. Journal of Human Resources in Hospitality \& Tourism 6(2): 109-134.

Gallardo E, Sánchez-Cañizares SM, López-Guzmán T and Nascimento Jesus MM (2010) Employee satisfaction in the Iberian hotel industry: The case of Andalusia (Spain) and the Algarve (Portugal). International Journal of Contemporary Hospitality Management 22(3): 321-334.

Gamero C (2004) Satisfacción laboral de los asalariados en España. Especial referencia a las diferencias por género. Cuadernos de Economía 27(74): 109-145.

Gamero C (2005) Análisis microeconómico de la satisfacción laboral. Madrid: Consejo Económico y Social.

Gamero C (2007) Satisfacción laboral y tipo de contrato en España. Investigaciones Económicas 31(3): 415-444.

Varela J and García T (2006) Structural relationships between organizational service orientation, contact employee job satisfaction and citizenship behaviour. International Journal of Service Industry Management 17(1): 23-50.

Green F (2010) Well-being, job satisfaction and labour mobility. Labour Economics 17(6): 897903.

Gunlu E, Aksarayli M and Perçin NS (2010) Job satisfaction and organizational commitment of hotel managers in Turkey. International Journal of Contemporary Hospitality Management 22(5): 693 - 717.

Hamermesh, DS (1977) Economic aspects of job satisfaction. In: Ashenfelter O and Oates W (eds.) Essays in Labor Market and Population Analysis. New York: J. Wiley \& Sons: 5372 . 
Harter JK and Arora R (2008) The impact of time spent working and job fit on well-being around the world. In Diener E, Kahneman D and Helliwell J International Differences in WellBeing. Oxford, Oxford University Press DOI:10.1093/acprof:oso/9780199732739.003.0013

Judge TA, Thoresen CJ, Bono JE and Patton GK (2001) The Job Satisfaction-Job Performance Relationship: A Qualitative and Quantitative Review. Psychological Bulletin 127(3): 376-407.

Kim K and Jogaratnam G (2010) Effects of Individual and Organizational Factors on Job Satisfaction and Intent to Stay in the Hotel and Restaurant Industry. Journal of Human Resources in Hospitality \& Tourism 9(3): 318-339.

Lam T, Baum T and Pine R (2001) Study of managerial job satisfaction in Hong Kong's Chinese Restaurant. International Journal of Contemporary Hospitality Management 13(1): 3542.

Lam T, Zhang H and Baum T (2001) An investigation of employees' job satisfaction: the case of hotels in Hong Kong. Tourism Management 22: 157-165.

Lévy-Garboua L, Montmarquette C and Simonnet V. (2007) Job satisfaction and quits. Labour Economics 14(2): 251-268.

Lillo-Bañuls A and Casado-Díaz JM (2015) Exploring the relationship between educational mismatch, earnings and job satisfaction in the tourism industry. Current Issues in Tourism 18(4): 361-375. DOI: 10.1080/13683500.2014.915796.

López-Cabarcos MA, Machado-Lopes-Sampaio-de Pinho AI and Vázquez-Rodríguez P (2015) The Influence of Organizational Justice and Job Satisfaction on Organizational Commitment in Portugal's Hotel Industry. Cornell Hospitality Quarterly 5(3): 258-272.

MacKerron G (2012) Happiness economics from 35,000 feet. Journal of Economic Surveys 26(4): $705-735$.

Muñoz-Bullón F (2009). The gap between male and female pay in the Spanish tourism industry. Tourism Management 30(5): 638-49.

Oswald AJ (2002) Are you happy at work? Job satisfaction and work-life balance in the US and Europe. Mimeo, University of Warwick.

Pan FC (2015) Practical application of importance-performance analysis in determining critical job satisfaction factors of a tourist hotel. Tourism Management 46: 84-91.

Pavesic DV and Brymer RA (1990) Job satisfaction: What's happening to the young managers? The Cornell Hotel and Restaurant Administration Quarterly 30(4): 90-96.

Rahman M and Sanzi A (1995) A comparison of organizational structure, job stress and satisfaction in audit and management advisory systems (MAS) in CPA firms. Journal of Management Issues 7(3): 290-305.

Santos LD and Varejão J (2007) Employment, pay and discrimination in the tourism industry. Tourism Economics 13(2): 225-240.

Sarker SJ, Crossman A and Chinmeteepituck P (2003) The relationships of age and length of service with job satisfaction: an examination of hotel employees in Thailand. Journal of Managerial Psychology 18(7/8):745-758.

Simón H; Casado-Díaz JM and Driha O (2015) The gender wage gap in hospitality, Sixth Workshop on Tourism, University of Guanajuato, Mexico, 16-18 September 2015.

Skalpe O (2007). The CEO gender pay gap in the tourism industry - Evidence from Norway. Tourism Management 28(3): 845-53.

Shields MA and Ward M (2001) Improving nurse retention in the national health service in England: the impact of job satisfaction on intentions to quit. Journal of Health Economics 20(5): 677-701.

Smith K, Gregory SR and Cannon D (1996). Becoming an employer of choice: Assessing commitment in the hospitality workforce. International Journal of Contemporary Hospitality Management, 8(6): 3-9.

Torrent-Sellens J, Velazco-Portocarrero J and Viñas-Bardolet C (2016) Knowledge-Based Work and Job Satisfaction: Evidence from Spain. Journal of the Knowledge Economy, published online 23 January 2016 doi:10.1007/s13132-015-0349-1. 
Veenhoven, R. (2000). The four qualities of life. Ordering concepts and measures of the good life. Journal of Happiness Studies, 1(1):1-39.

Warr P (1999) Wellbeing and the Workplace. Russell Sage Foundation, New York.

Yang JT (2010) Antecedents and consequences of job satisfaction in the hotel industry. International Journal of Hospitality Management 29(4): 606-619.

Zhu Y (2013) A review of job satisfaction. Asian Social Science 9(1): 293-298. 
Annex

[Table A.1 here]

[Figure A.1 here]

[Figure A.2 here] 